\title{
Is there a Gap between Research and Practice? Reflecting on the motivational climate and attitudes towards physical education ¿Hay una brecha entre la investigación y la práctica? Reflexionando sobre el clima motivacional y actitudes hacia la educación física \\ *Paulo Pereira, **Fernando Santos, ***Daniel Marinho \\ *Polytechnic Institute of Porto (Portugal), **Polytechnic Institute of Porto and Viana do Castelo (Portugal), $* * *$ University of Beira Interior (Portugal)
}

\begin{abstract}
Over the last decades, motivational climate and students' attitudes towards physical education has been extensively discussed by the teaching community and investigated in many socio-cultural contexts. Nevertheless, in some cases, there are numerous discrepancies between research and practice due to the cultural relevancy of physical education across educational systems, policy and teachers' beliefs and practices. The purpose of this article is to analyze the existence of potential gaps between research and practice across socio-cultural contexts and suggest guidelines for future research and practice on motivational climate and attitudes towards physical education. In order to effectively create and disseminate knowledge, a broader focus on multiple contextual variables is needed which might help develop policies and evidencebased guidelines that reflect contextual intricacies across several socio-cultural contexts. In this article, we explore potential avenues for research and practice that might help increase our understanding about students' attitudes towards physical education through an appropriate motivational climate.
\end{abstract}

Keywords: education, teacher, youth, schools.

Resumen. A lo largo de las últimas décadas, el clima motivacional y las actitudes de los estudiantes hacia la educación física han sido ampliamente discutidos por la comunidad docente e investigados en muchos contextos socioculturales. Sin embargo, en algunos casos, existen numerosas discrepancias entre la investigación y la práctica debido a la relevancia cultural de la educación física en todos los sistemas educativos, políticas y creencias y prácticas de los docentes. El propósito de este artículo es analizar la existencia de posibles brechas entre la investigación y la práctica de la kinesiología en contextos sociocultural y sugerir pautas para futuras investigaciones y prácticas sobre el clima motivacional y las actitudes hacia la educación física. Para crear y difundir el conocimiento de manera efectiva, se necesita un enfoque más amplio en múltiples variables de contexto que puedan ayudar a desarrollar políticas y pautas basadas en evidencia que reflejen las complejidades contextuales en una variedad de contextos socioculturales. En este artículo, exploramos posibles vías de investigación y práctica que podrían ayudar a aumentar nuestra comprensión sobre las actitudes de los estudiantes hacia la educación física a través de un clima motivador apropiado.

Palabras clave: educación, docente, juventud, colegios.

\section{Introduction}

Many researchers and practitioners such as Physical Education (PE) teachers (Merino-Barrero, Pedreño, Valenzuela, \& Fernandez-Rio, 2019; Dyson, 2014; Sallis et al., 2012) have devoted their time and efforts to investigating how to foster quality of PE in several educational systems and countries. The need to foster quality PE drives for the increased levels of physical inactivity across the world, as well as lack of motor proficiency and intrinsic motivation towards this discipline (Onofre, 2017). Therefore, the quality of PE throughout childhood and adolescence is dependent on students' motivation towards physical and sport activities, motor competence and life skill development (McLennan \& Thompson, 2015). However, applying these pedagogical principles and attaining these goals is not unproblematic. Such variables have motivated researchers to understand how to bridge the gap between research and PE teachers' practices for better student outcomes (Quennerstedt, \& Larsson, 2015).

Fecha recepción: 30-12-19. Fecha de aceptación: 19-06-20

Fernando Santos

fsantos@ese.ipp.pt
Conducting research-to-practice efforts that contribute to enhance the quality of PE is challenging, but indeed a priority for many stakeholders, organizations and researchers (Martinek \& Ruiz, 2005; Wallhead \& O’Sullivan, 2005). Such challenges include helping PE teachers adopt evidence-based practices, develop an appropriate curriculum, and consider communities and students' needs (Casey \& MacPhail, 2018). McLennan and Thompson (2015) highlighted how quality of PE is not exclusively dependent on physical fitness and/ or motor skill development. These researchers, alongside others (Santos, Neves, \& Parker, 2020) alluded to the role played by PE teachers and school institutions to provide learning opportunities conducive to students' life skills development. Conversely, Onofre (2017) indicated PE teachers' and school institutions' roles and responsibilities to foster autonomous sport participation throughout the life span through an appropriate motivational climate. Therefore, the quality of $\mathrm{PE}$ encompasses multiple contextualized variables that reflect intended outcomes and need to be considered. Ferrer-Caja and Weiss (2000) have highlighted that investigating «...variations in motivated behaviors such as choice, effort, and persistence in physical activity is a primary objective of researchers and educators in the physical domain» (p.268). 
Previous studies have stated the importance of fostering a motivational climate that provides students with high quality developmental experiences in PE that may (a) increase physical activity and sport participation through adulthood, (b) develop life skills needed throughout the life span and (c) help overcome current societal challenges such as obesity and antisocial behaviors (Curtner-Smith, 1999; Hastie \& Sharpe, 1999; Shek, Ma, \& Sun, 2011; Jung, Ressler, \& Linder, 2018; Quennerstedt, 2018). Achieving these developmental goals may also positively influence students' attitudes towards PE. This holistic approach towards PE has enabled an understanding about the role played by motivational climate and students' attitudes towards PE (Escartí, Gutiérrez, Pascual, \& Wright, 2013).

\section{Background}

Several theories and postulates such as achievement goal theory and self-determination theory (Ntoumanis \& Biddle, 1999; Deci \& Ryan, 2008; Smith et al., 2015; Molina, 2018) have been used to understand the features of quality PE settings. As such, investigations have attempted to understand how to foster an intrinsically motivating environment in PE that may lead to long-lasting sport participation and increased levels of physical activity $(\mathrm{Li}$, Wright, Rukavina, \& Pickering, 2008). Further, students' attitudes towards PE have also been explored (Subramaniam \& Silverman, 2007; Woodson-Smith, Dorwart, \& Linder, 2015; Evangelou \& Digelidis, 2018) to provide an understanding about students' positive and negative developmental experiences in PE. Thus, considering the influential role played by the motivational climate and attitudes toward PE in longterm sport participation and physical activity (Morgan \& Carpenter, 2002; Robertson-Wilson, Baker, Derbyshire, \& Côté, 2003), reviews have been conducted to analyse the motivational climate in PE, interventions focused on changing students' attitudes towards $\mathrm{PE}$, and/or rigor in previous research designs (Braithwaitea, Sprayb, \& Warburton, 2011; Silverman, 2017). Nevertheless, there is the need to critically reflect on the literature on motivational climate and attitudes towards PE to analyze the connection between research and the challenges placed by practice across socio-cultural contexts. This approach has numerous implications for researchers and stakeholders such as PE teachers and policy makers.

Despite the numerous calls for better PE across sociocultural settings that may enable sport participation and physical activity across the life span (Casey \& MacPhail, 2018; Robertson-Wilson et al., 2003), research, in some cases, still has limited impact on PE teachers' practices. In some cases, such limited impact drives from the way research questions are framed and research priorities defined. First, we should have in mind that a range of variables influence PE differently across socio-cultural contexts. For example, Jung and Wright (2012) examined the implementation of Hellison's (2011) model in South Korea and highlighted the challenges of fostering an autonomy-based climate due to the fact teachers were traditionally seen as «power controllers» (p. 155). Baptista et al. (2018) conducted an outcome evaluation of a teacher training program in Timor-
Leste focused on Hellison's (2011) model. These researchers highlighted the number of certified PE teachers in TimorLeste is still lower than expected as more efforts should be directed towards teacher training. Second, there are variables beyond the motivational climate and students' attitudes towards PE that may need to be included in research designs if the aim is to ultimately improve PE teachers' practices and students' outcomes. The nature of PE teachers' practices and the challenges inherent to striving for quality PE may require a more holistic approach to research and practice (i.e., considering a vast array of variables such as teacher training and policy) across socio-cultural contexts. On one hand, researchers may need to reflect on how research projects are framed in their contexts and provide insight to solve real world problems. On the other hand, PE teachers may need to consider how to operate with the aim of improving the quality of PE in a sustainable manner. This debate may enable a better alignment between research and practice (Côté \& Hancock, 2016) by helping PE teachers use evidence-based practices and researchers develop practice-based evidence.

\section{Purpose}

The purpose of this article is to provide insights about potential gaps between research and practice across sociocultural contexts and suggest guidelines for future research and practice on motivational climate and attitudes towards PE. This insights article considers the experiences and reflections made by the authors within the Portuguese context and on the existent body of literature which may be useful for researchers and practitioners across a range of contexts.

Motivational climate research and attitudes toward physical education: What do we need to know?

Over the last decade, research on motivational climate in PE has provided valuable insight on how to provide solid grounds for meaningful participation in PE (Cid et al., 2019; Jaakkola, Yli-Piipari, Barkoukis, \& Liukkonen, 2017; Liukkonen, Barkoukis, Anthony, \& Jaakkola, 2010; MorenoMurcia, Sicilia, Cervelló, Huéscar, \& Dumitru, 2011). For example, Moreno-Murcia et al. (2011) conducted a study with 565 children from a Spanish setting that aimed to test a motivational model focused on the relationships between situational and dispositional motivation and self-reported discipline. These researchers have alluded to the fact perceived motivational climate and students' motivational disposition are variables that may be used to predict selfreported discipline. More recently, Cid et al. (2019) conducted with 618 students from Portuguese public schools in order to understand the motivational climate, students' satisfaction of basic psychological needs as well as the role played by variables such as PE grades and intention to practice sport. Findings showed perceived competence had a positive relationship with students' autonomous motivation, PE grade and intention to practice sport. Most research has alluded to the notion that motivational climate influences students' perspectives toward PE and intention to perform sport and physical activity in the future through quantitative designs 
(Escartí \& Gutiérrez, 2001; Morgan \& Carpenter, 2002; Mendes, Martins, \& Costa, 2006; Warburton, 2017). However, are students' perceptions about PE only a by-product of an appropriate motivational climate?

Several theories have been used by researchers to conceptualize motivational climate (Ames \& Ames, 1984; Morgan, 2017). Of these theories, achievement goal theory has been largely used (Ames \& Ames, 1984). Considering the work conducted by these researchers, achievement goal theory focuses on individuals' desire to attain competence through two types of objectives: task-oriented objectives and ego-oriented objectives. Task-oriented goals reflect an individual's desire to improve his/her performance, learn more and highlights the role played by individual improvement and an intrinsically motivating climate. In contrast, egooriented objectives outline the importance of outperforming others and have been linked to the lack of intrinsic motivation, low competence and ultimately lack of engagement in PE (Ntoumanis \& Biddle, 1999). Thus, considering achievement goal theory's tenets, motivational climate has been considered either focused on mastery or competitiveness (Ames \& Archer, 1988). Previous research (Escartí \& Gutiérrez, 2001; Warburton, 2017) has shown that a climate of competitiveness may lead to negative outcomes (Valero, Martínez, \& Botella, in press) such as less perceived competence when compared to a climate of mastery. Conversely, self-determination theory (Deci \& Ryan, 2008) has also been utilised to understand students' motivation towards PE (Chirkov, 2009; SalazarAyala \& Gastélum-Cuadras, 2020). This theory considers motivation within a continuum whereas students' move from being extrinsically to intrinsically motivated towards PE (Deci \& Ryan, 2008). Indeed, intrinsically motivated students may have increased chances of participating in sport and physical activity throughout adulthood (Villarino, Valeiro, Reboredo, \& Costa, 2017; Cid et al., 2019).

Positive attitudes toward PE have suggested an increased likelihood of sport participation across the life span (Biddle \& Goudas, 1996; Subramaniam \& Silverman, 2007). The twocomponent view of attitude is a framework that has been largely used in previous studies (Evangelou \& Digelidis, 2018; Kaj et al., 2015; Woodson-Smith et al., 2015). This framework focuses on two components: cognition and affect. On one hand, cognition refers to students' beliefs, feelings and perspectives towards $\mathrm{PE}$ and reflects the perceived value of PE. For example, a student might feel PE helps improve physical fitness. On the other hand, affect has been linked to students' expressions of feelings towards PE and their evaluation of this discipline. A student might feel the PE teacher does not provide appropriate support to improve physical fitness. Thus, attitudes toward PE directly influence students' behaviors and reflect how PE teachers are able to foster sport participation outside the school environment. Constantinides and Silverman (2018) conducted a study to examine the attitudes toward PE of 763 Cypriot students with ages ranging from 10 to 12 years and found the curriculum is viewed as less useful as students move to other grades. Findings showed there was a decrease in students' perceived usefulness of the PE teacher and curriculum (i.e., cognitive component) as the grade increased. Reina, Hutzler, IniguezSantiago, and Moreno-Murcia (2019) analysed associations between students' ability beliefs and attitudes toward inclusion within the Spanish context. These researchers found that students with higher scores for ability beliefs had a less positive attitude toward inclusion in PE. Mohammed and Mohammad (2012) aimed to examine 2700 students' attitudes towards PE in Kuwait. Findings showed students believed PE was conducive to health benefits and provided a fun and positive atmosphere. Further, several variables have been considered important while investigating attitudes toward PE such as «... prior experience, either successful or unsuccessful; feedback received from outside sources; societal expectations for appropriateness of engagement; perceptions of usefulness of material; and feedback received from peers and teacher» (Scrabis-Fletcher \& Silverman, 2017, p. 86). Therefore, researchers have raised concerns about how to sustain positive attitudes toward PE across youth's participation in school and develop a context conducive to long-lasting sport participation and positive health (Woodson-Smith et al., 2015).

It has been consensual that

...with the knowledge we currently possess, it seems reasonable to predict that, in cultures with democratic values, where giving opportunities to all students is a primary educational value, the mastery motivational climate will favor not only the intrinsic motivation and the intention of the students to carry out physical activity and sport, but also the personal and social development of the pupils (Escartí \& Gutiérrez, 2001,p. 8).

Hence, research on motivational climate and attitudes toward PE have considered the need to acknowledge the role played by context and variables such as teacher education, policy, students' competence and the social forces present in diverse socio-cultural settings (Moyano, Pacheco, \& Urbieta, 2018; Baños \& Arrayale, 2020). Nevertheless, studies that have analyzed «...the relative influence of significant others changes according to the developmental status of individuals and contexts» (Weigand, Sam Carr, Petherick, \& Taylor, 2001, p.8) are still scarce in some sociocultural contexts such as Portugal. The socio-cultural context and related variables are crucial to explain the motivational climate and attitudes toward PE (Quennerstedt, \& Larsson, 2015). In other words, «cultural, institutional and historical contexts of PE can create different conditions for teaching and learning» (Quennerstedt \& Larsson, 2015, p.569). For example, in Portugal, there are diverse contextualized variables that directly impact PE. For example, PE in primary schools may be delivered by a PE or generalist teacher (Neves, 2019). Throughout teacher education programs, generalist teachers are exposed to few courses specifically focused on PE. Thus, generalist teachers might have, in some cases, limited ability to create an intrinsically motivated climate and generate positive attitudes towards PE (Neves, 2001). Previous studies (Santos, Farias, Hilvoorde, Gould, \& Pereira, 2020) have attempted to provide a nuanced understanding about the particularities of PE in primary schools. To disseminate a set of contextualized research and practical implications, it is necessary to understand the need to consider motivational climate and attitudes towards PE as outcomes of a given education system and a range of context variables. This approach may help improve the quality of PE and impact 
research and practice, and potentially change the current status quo whereas PE is, in some cases, considered a less important discipline (Neves, 2001).

In sum, previous studies have provided great insight on how motivational climate may be structured by PE teachers to increase student participation, engagement and competence that ultimately leads to positive attitudes toward $\mathrm{PE}$ and the intention to engage in physical education and sport (Côté \& Fraser-Thomas, 2007; Fraser-Thomas, Côté, \& Deakin, 2008). Nevertheless, certain variables such as student perceived competence have been investigated separately which may limit our understanding about the role played by context, specifically in socio-cultural contexts whereas research and practice are still distant (Braithwaitea et al., 2011; Quennerstedt \& Larsson, 2015). In order to effectively create and disseminate knowledge, a broader focus on contextual variables is needed which might help develop policies and evidence-based guidelines that reflect contextual intricacies across a range of socio-cultural contexts (Guwatudde et al., 2016).

\section{Implications for Research and Practice}

Several educational reforms across the world (Ministry of Education, 2007; Silva, Marques, Mata, \& Rosa, 2016; Statistics Canada, 2014) have been conducted to increase sport participation among students and generate better outcomes such as positive attitudes toward PE, higher perceived competence and a fun/enjoyable climate. Thus, research on motivational climate and attitudes toward PE has the power to help shed light on real-world problems with tremendous impact across a range of socio-cultural contexts (Sevil, García-González, Abós, Generelo, \& Aibar, 2019). However, many schools are still «...fearful of receiving negative publicity when participating in research» (Quennerstedt \& Larsson, 2015, p.568) and researchers still struggle to influence practice and develop practice-based evidence. In this sense, it could be necessary to consider integrating theory and contextual variables through appropriate research designs. Appropriate research designs may (a) be defined through discussions with stakeholders such as PE teachers and school administrators, (b) acknowledge the influence of context variables and identify the most relevant ones to investigate motivational climate and attitudes towards PE, and (c) focus on knowledge translation. First, context variables may help explain the relationship between teachers' instructional efforts within a specific socio-cultural context and students' outcomes. An analysis focused on how and why teachers foster a specific motivational climate and attitudes towards PE is needed. For example, in the Portuguese context, throughout the last decades some researchers have criticised teacher education programs and the lack of value given to PE (Neves, 2001) as this line of inquiry has been considered crucial (Sá \& Costa, 2009). However, there is still the need to further understand the connection between teacher education programs, motivational climate and students' attitudes towards PE. A thorough assessment of the current teacher education program that considers motivational climate and students' attitudes as desired outcomes is needed. Such as approach could facilitate knowledge translation and the bridge the potential gap between research and practice.

If an appropriate motivational climate that leads to positive attitudes toward PE is to be created on a larger scale, future studies may need to provide a more diverse and integrative outlook. Such integrative outlook could be facilitated by policy makers through a national research program whereas research priorities per school and/or district are defined and consider context variables deemed crucial for actual change in PE. This national research program could serve as a guide for researchers to focus on the most relevant context variables that need to be investigated. Evidence-informed decisions and a concern towards practice-based evidence may be key to improve students' experiences in PE since early childhood until adolescence. This is a necessary step within the Portuguese context, and possibly among other contexts, to create impactful research that reaches PE teachers, school administrators, parents and ultimately students. Further, an integrative outlook may highlight how variables such as policy, curriculum, teachers' instructional efforts, student outcomes and teacher education influence motivational climate and attitudes toward PE.

Neves (2001), reflecting on the Portuguese context, raised awareness about how research has not reached stakeholders who still have a narrow perspective on PE. The extent to which researchers and practitioners are open to develop research-to-practice partnerships and contextualized knowledge may be influenced by a set of social forces such as the way PE and research are valued, how the teaching profession is portrayed by society, professional development opportunities, the priorities set by policy makers, the need to publish, among other factors (Quennerstedt \& Larsson, 2015). Therefore, we invite researchers to (a) develop collaborate efforts to understand what quality PE means across age groups/grade levels, (b) help increase practitioners' openness to research and (c) use research designs that include context variables to understand why there is a specific motivational climate and a set of attitudes toward PE and what needs to be considered moving forward. Considering these notions, an outcome evaluation of teacher education programs through motivational climate and students' attitudes toward PE may be necessary to inform future education reforms and research priorities. A process evaluation of teacher education programs could also help understand why there is a specific motivational climate and a set of attitudes toward PE. This process evaluation may include an analysis of the number of hours focused on specific grade levels and types of learning experiences. Research on how practitioners use evidence is also needed to assess knowledge translation. Taking into consideration the intricacies of the Portuguese context, we aim to prompt reflection about $\mathrm{PE}$ through the case of Portugal and highlight what do we know about motivational climate and attitudes toward PE and current challenges.

\section{Conclusions}

The purpose of this article is to analyze the existence of potential gaps between kinesiology research and practice and suggest guidelines for future research and practice on motivational climate and attitudes towards PE. We used our 
experiences and reflections on the Portuguese context to prompt reflection about this topic. Previous research has provided great insight on motivational climate and attitudes towards PE. However, there are still concerns about the disconnect between research and practice in some contexts. In this sense, we urge researchers to develop a reflection about how investigations could better reflect concrete practical issues and «get at» the nature of providing an appropriate motivational climate that generates positive attitudes towards PE. To do so, looking beyond students' attitudes towards PE and the motivational climate experienced in PE may be necessary. To help bridge the gap between research and practice, other variables such as teacher education, curriculum and social pressures may need to be considered.

\section{Acknowledgments}

This work was supported by the Portuguese Coaches Confederation and by the National Funds through the FCT Fundação para a Ciência e a Tecnologia, I.P., under the scope of the project UIDB/05198/2020 (Centre for Research and Innovation in Education, inED). We would like to thank all the coaches and researchers who helped conduct this study and further understand knowledge translation processes.

\section{References}

Ames, C., \& Ames, R. (1984). Systems of student and teacher motivation: Toward a qualitative definition. Journal of Educational Psychology, 76(4), 535-556. doi: 10.1037/0022-0663.76.4.535

Ames, C., \& Archer, J. (1988). Achievement goals in the classroom: Students' learning strategies and motivation processes. Journal of Educational Psychology, 80(3), 260-267.

Baños, R., \& Arrayale, E. (2020). Predicción del aburrimiento en la educación física a partir del clima motivacional. Retos, 38(1), 83-88.

Baptista, C., Santos, F., Romão, A., Corte-Real, N., Dias, C., Dias, T., Martinek, T., Regueiras, L., Fonseca, A. (2018). Formação de professores em Timor-Leste: Um modelo assente na responsabilidade pessoal e social através da educação física. Revista Portuguesa de Ciências do Desporto, 18(3), 62-81.

Biddle, S., \& Goudas, M. (1996). Analysis of children's physical activity and its association with adult encouragement. Journal of School Health, 66(2), 75-78.

Braithwaitea, R., Sprayb, C. M., \& Warburton, V.E.(2011). Motivational climate interventions in physical education: A meta-analysis. Psychology of Sport and Exercise, 12(6), 628-638. doi: 10.1016/ j.psychsport.2011.06.005

Casey, A., \& MacPhail, A. (2018). Adopting a models-based approach to teaching physical education. Physical Education and Sport Pedagogy, 23(3), 294-310. doi: 10.1080/17408989.2018.1429588

Chirkov, V. (2009). A cross-cultural analysis of autonomy in education: A self-determination theory perspective. Theory and Research in Education, 7(2), 253-262. doi: 10.1177/1477878509104330

Cid, L., Pires, A., Borrego, C., Duarte-Mendes, P., Teixeira, D. S., Moutão, J. M., \& Monteiro, D. (2019). Motivational determinants of physical education grades and the intention to practice sport in the future. PLoS ONE, 14(5), 217-218. doi: 10.1371/ journal.pone.0217218

Constantinides, P., \& Silverman, S. (2018). Cypriot urban elementary students' attitude toward physical education. Journal of Teaching in Physical Education,, 37, 69-77. doi: 10.1123/jtpe.2016-0235

Côté, J., \& Fraser-Thomas, J. (2007). Introductions to sport psychology:
A Canadian perspective In P. Crocker (Ed.), Youth involvement in sport (pp. 266-294). Toronto, ON: Pearson Prentice Hall.

Côté, J., \& Hancock, D. (2016). Evidence-based policies for youth sportprogrammes. International Journal of Sport Policy and Politics, 8(1), 51-65.

Curtner-Smith, M. D. (1999). The more things change the more they stay the same: Factors Influencing teachers' interpretations and delivery of national curriculum physical education. Sport, Education and Society, 4(1), 75-97.

Deci, E. L., \& Ryan, R. M. (2008). Self-determination theory: a macrotheory of human motivation, development, and health. Canadian Psychology, 49(3), 182-185.

Dyson, B. (2014). Quality physical education: A commentary on effective physical education teaching. Research Quarterly for Exercise and Sport, 85(2), 144-152. doi: 10.1080/ 02701367.2014.904155

Escartí,A., \& Gutiérrez, M.(2001). Influence of the motivational climate in physical education on the intention to practice physical activity or sport. European Journal of SportScience, 1(4), 1-12. doi: 10.1080/ 17461390100071406

Escartí,A., Gutiérrez, M., Pascual, C., \& Wright, P.(2013). Observación de las estrategias que emplean los profesores de educación física para enseñar responsabilidad personal y social. Revista de Psicología del Deporte, 22(1), 159-166.

Evangelou, E., \& Digelidis, N. (2018). Students' attitudes and predispositions toward physical education in Greece. Journal of Physical Education and Sport, 18(3), 1624-1631. doi: 10.7752/ jpes.2018.03238

Ferrer-Caja, E., \& Weiss, M. (2000). Predictors of intrinsic motivation among adolescent students in physical education. Research Quarterly for Exercise and Sport, 71(3), 267-279. doi: 10.1080/ 02701367.2000.10608907

Fraser-Thomas, Côté, J., \& Deakin, J. (2008). Understanding dropout and prolonged engagement in adolescent competitive sport. Psychology of Sport and Exercise, 9(5), 645-662. doi: 10.1016/ j.psychsport.2007.08.003

Guwatudde, D., Kirunda, B. E., Wesonga, R., Mutungi, G., Richard Kajjura, Kasule, H., ... Bahendeka, S. K. (2016). Physical activity levels among adults in Uganda: Findings from a countrywide crosssectional survey. Journal of Physical Activity and Health, 13, 938 945. doi: 10.1123/jpah.2015-0631

Hastie, P., \& Sharpe, T. (1999). Effects of a Sport Education Curriculum on the Positive Social Behavior of At-Risk Rural Adolescent Boys. Journal of Education for Students Placed at Risk, 4(4), 417-430.

Jaakkola, T., Yli-Piipari, S., Barkoukis, V., \& Liukkonen, J. (2017). Relationships among perceived motivational climate, motivational regulations, enjoyment, and PAparticipation among Finnish physical education students. International Journal of Sport and Exercise Psychology, 15(3), 273-290. doi: 10.1080/1612197X.2015.1100209

Jung, J., Ressler, J., \& Linder, A. (2018). Exploring the hidden curriculum in physical education. Advances in Physical Education, 8(1), 253262.

Jung, J., \& Wright, P. (2012). Application of Helisson's responsibility model in South Korea: A multiple case study of 'at-risk' middle school students in physical education. Agora para la Educación Física y el Deporte, 14(2), 140-160.

Kaj, M., Saint-Maurice, P. F., Karsai, I. n., Vass, Z. n., Csá nyi, T. s., y, . . . Federation, H. S. S. (2015). Associations between attitudes toward physical education and aerobic capacity in Hungarian high school students. Research Quarterly for Exercise and Sport, 86, 74-81. doi: 10.1080/02701367.2015.1043229

Li, W., Wright, P. M., Rukavina, P.B., \& Pickering, M. (2008). Measuring student's perceptions of personal and social responsability and the relationship to intrinsic motivation in urban physical education. Journal of Teaching in Physical Education, 27(2), 167-178. doi: 10.1123/jtpe.27.2.167 
Liukkonen, J., Barkoukis, V., Anthony, W., \& Jaakkola, T. (2010). Motivational climate and students' emotional experiences and effort in physical education. The Journal of Educational Research, 103(5), 295-308. doi: 10.1080/00220670903383044

Martinek, T. J., \& Ruiz, L. M. (2005). Promoting positive youth development through a values-based sport program. Revista Internacional de Ciencias del Deporte, 1(1), 1-13. doi:10.5232/ ricyde2005.00101

McLennan, N., \& Thompson, J. (2015). Quality physical education (QPE). Guidelines for policy-makers. Paris, France: UNESCO.

Mendes, J., Martins, J., Costa, F. (2016). A percepção do clima motivacional em alunos de professores estagiários e de professores cooperantes. Gymnasium, 1(2), 1-11.

Merino-Barrero, J., Pedreño, N., Valenzuela, A., \& Fernandez-Rio, J. (2019). Impact of a sustained TPSR program on students' responsibility, motivation, sportsmanship, and intention to be physically active. Journal of Teaching in Physical Education, Advance online publication.

Ministry of Education. (2007). The New Zealand Curriculum. Wellington: Learning Media.

Mohammed, H., \& Mohammad, M. (2012). Students opinions and attitudes towards physical education classes in Kuwait public schools. College Student Journal, 46(3), 550-566.

Molina, F.(2018). Educación física, calidad de vida y la nueva sociología delainfancia: Repensando la metodología mixta en sociología. Retos, 33(1), 69-73.

Moreno-Murcia, J.A., Sicilia, A., Cervelló, E., Huéscar, E., \& Dumitru, D. C. (2011). The relationship between goal orientations, motivational climate and self-reported discipline in physical education. International Journal of Sports Science \& Medicine, 10(1), 119-129.

Morgan, K. (2017). Reconceptualizing motivational climate in physical education and sport coaching: An interdisciplinary perspective. Quest, 69(1), 95-112. doi: 10.1080/00336297.2016.1152984

Morgan, K., \& Carpenter, P. (2002). Effects of manipulating the motivational climate in physical education lessons. European Physical Education Review, 8(3), 207-229.

Moyano, A., Pacheco, M., Urbieta, C. (2018). Procesos psicosociales en Educación Física: actitudes, estrategias y clima motivacional percibido. Retos, 34(1), 19-24.

Neves, R. (2001). Educação Física no $1^{\circ}$ ciclo ensino básico. Do baldio pedagógico à construção curricular. Lecturas: Educación Física y Deportes, 31(6), 1-2.

Neves, R. (2019). Os modelos de docência da educação física no $1^{\circ}$ ceb - visões dos gestores. Retos, 35(1), 107-112.

Ntoumanis, N., \& Biddle, S. (1999). A review of motivational climate in physical activity. International Journal of Sport Sciences, 17(8), 643-665. doi:10.1080/026404199365678

Onofre, M. (2017). A qualidade da educação física como essência da promoção de uma cidadania ativa e saudáve. Retos, 31, 328-333.

Quennerstedt, M., \& Larsson, H. (2015). Learning movement cultures in

physical education practice. Sport, Education and Society, 20(5), 565572. doi:10.1080/13573322.2014.994490

Quennerstedt, M. (2018). Healthying physical education - on the possibility of learning health. Physical Education and Sport Pedagogy, 24(1), 1-15. doi:10.1080/17408989.2018.1539705

Reina, R., Hutzler, Y., Iniguez-Santiago, M. C., \& Moreno-Murcia, J. A. (2019). Student attitudes toward inclusion in physical education: The impact of ability beliefs, gender, and previous experiences. Adapted Physical Activity Quarterly, 36, 132-149. doi: 10.1123/ apaq.2017-0146

Robertson-Wilson, J., Baker, J., Derbyshire, E., \& Côté, J. (2003). Childhood physical activity involvement in active and inactive female adults. Avante, 9(1), 1-8.

Sá, C., Costa, F. (2009). A influência socializadora da formação inicial em Educação Física. Perceções dos protagonistas e unidade conceptual interpares. Sociedade Portuguesa de Educação Física, 34(1), 95-108.

Salazar-Ayala, C., Gastélum-Cuadras, G. (2020). Teoría de la autodeterminación en el contexto de educación física: Una revisión sistemática. Retos, 38(1), 838-844.

Sallis, J., McKenzie, T., Beets, M., Beighle, A., Erwin, H., \& Lee, S. (2012). Physical education's role in public health: Steps forward and backward over 20 years and HOPE for the future. Research Quarterly for Exercise \& Sport, 83(2), 125-135. doi: 10.1080/ 02701367.2012.10599842

Santos, F., Farias, C., Hilvoorde, I., Gould, D., Pereira, P. (2020). Implementing positive youth development in primary physical education: The learning trajectories of a physical education department head. Retos, 38(1), 528-536.

Santos, F., Neves, R., \& Parker, M. (2020). Future pathways in implementing the teaching personal and social responsibility model in Spain and Portugal. Retos, 38(2)

Scrabis-Fletcher, K., \& Silverman, S. (2017). Student perception of competence and attitude in middle school physical education. The Physical Educator, 74, 85-103. doi: 10.18666/TPE-2017-V74-I16557

Sevil, J., García-González, L., Abós, A., Generelo, E., \& Aibar, A. (2019). Can high schools be an effective setting to promote healthy lifestyles? Effects of a multiple behavior change intervention in adolescents. Journal of Adolescent Health, 64(4), 478-486. doi:10.1016/j.jadohealth.2018.09.027

Shek, D., Ma, H., \& Sun, R. (2011). Development of a new curriculum in a positive youth development program: The project P.A.T.H.S. in Hong Kong. The Scientific World Journal, 11, 2207-2218.

Silva, I., Marques, L., Mata, L., \& Rosa, M. (2016). Orientações Curriculares para Educação-Escolar [Curricular guidelines for pre-school education]. Lisboa: Ministério de Educação/DireçãoGeral da Educação

Silverman, S. (2017). Attitude research in physical education: A review. Journal of Teaching in Physical Education,36, 303-312. doi:10.1123/ jtpe.2017-0085

Smith, N., Tessier, D., Tzioumakis, Y., Quested, E., Appleton, P., Sarrazin, P., ... Duda, J. (2015). Development and validation of the multidimensional motivational climate observation system (MMCOS). Journal of Sportand Exercise Psychology, 37(1), 20140059. doi: 10.1123/jsep.2014-0059.

Statistics Canada. (2014). Kids' sport. from Retrieved from http:// www.statcan.gc.ca/pub/11-008-x/2008001/article/10573-eng.htm

Subramaniam, P. R., \& Silverman, S. (2007). Middle school students' attitudes toward physical education. Teaching and Teacher Education, 23, 602-611. doi: 10.1016/j.tate.2007.02.003

Valero,A., Martínez, S., \& Botella, J. (in press). Metodología cooperativa para la mejora de actitudes disruptivas en educación física. Revista Internacional de Medicina y Ciencias de la Actividad Física y el Deporte, Advance online publication.

Villarino, M., Valeiro, M., Reboredo, B., Costa, F. (2017). Valoración de la escuela y la Educación Física y su relación con la práctica de actividad física de los escolares. Retos, 31(1), 312-315.

Wallhead, T., \& O’Sullivan, M. (2005). Sport education: Physical education for the new millennium? Physical Education and Sport Pedagogy, 10(2), 181-210. doi: 10.1080/17408980500105098

Warburton, V. (2017). Peer and teacher influences on the motivational climate in physical education: A longitudinal perspective on achievement goal adoption. Contemporary Educational Psychology, 51, 303-314. doi: 10.1016/j.cedpsych.2017.08.001

Weigand, D. A., Sam Carr, Petherick, C., \& Taylor, A. (2001). Motivational climate in sport and physical education: The role of significant others. European Journal of Sport Science, 1(4), 1-13. doi: 10.1080/17461390100071402

Woodson-Smith, A., Dorwart, C. E., \& Linder, A. (2015). Attitudes toward physical education of female high school students. The Physical Educator, 72, 460-479. 